\title{
TECTONOPHYSICS
}

Tectonophysics $258(1996) 85-101$

\section{A double island arc between Taiwan and Luzon: consequence of ridge subduction}

\author{
Tsanyao F. Yang ${ }^{a,{ }^{*}}$, Typhoon Lee ${ }^{\text {a.b }}$, Cheng-Hong Chen ${ }^{a}$, Shih-Nan Cheng ${ }^{\text {b }}$, \\ Ulrich Knittel $^{\text {c.l }}$, Raymundo S. Punongbayan ${ }^{\text {d }}$, Ariel R. Rasdas ${ }^{d}$ \\ "Department of Geology. National Taiwan University, 245 Choushan Road. Taipei 10770. Taiman, ROC \\ ${ }^{\mathrm{b}}$ Institute of Earth Sciences, Academia Sinica, Nankang P.O. Box 1-55, Taipei, Taiwan, ROC \\ "Institut fur Mineralogie und Lagerstattenlehre, Wullnerstr. 2, D-52056 Aachen. Germany \\ "Philippine Institute of Volcanology and Seismology, 29 Quezon Al'enue, Quezon City, Philippines'
}

Received 15 July 1994: accepted I November 1995

\begin{abstract}
Analysis of geomorphological, geochronological, geochemical and geophysical features in the segment of the TaiwanLuzon Arc between Taiwan and Luzon (the Bashi Segment) allows the recognition of a double arc structure. The two volcanic chains are separated by $50 \mathrm{~km}$ just north of Luzon $\left(18^{\circ} \mathrm{N}\right)$, and converge near $20^{\circ} \mathrm{N}$. Islets in the western chain are older and largely composed of volcanic rocks of Miocene to Pliocene age. They all show low relief, lateritic platforms and wave-cut terraces, and are covered by massive recrystallized limestone. In contrast, all active volcanoes in this segment of the Taiwan-Luzon Arc belong to the eastern chain, where most islets are Quaternary in age. The volcanoes have well-developed cone shapes, and well-preserved deposits of near-vent facies. Magmas of the eastern chain have higher $K_{\mathrm{Si}}$, $(\mathrm{La})_{n},(\mathrm{La} / \mathrm{Yb})_{n}$, and lower $\epsilon_{\mathrm{Nd}}$ than their counterparts at the same latitude in the western chain. Therefore, the magmas erupted in the eastern chain were derived from more enriched mantle sources than the magmas erupted in the western chain. Moreover, the available seismological data seem to suggest an abrupt increase of the dip angle from $30^{\circ}$ at $18^{\circ} \mathrm{N}$ to $80^{\circ}$ at $20^{\circ} \mathrm{N}$. Thus, the double arc structure is located in the region where the Benioff zone suddenly changes.

In analogy with the Lesser Antilles Arc, we propose a geodynamic model in which the double arc in the Bashi Strait is the tectonic manifestation of the subduction of the aseismic Scarborough Seamount Chain, the extinct mid-ocean ridge of the South China Sea. Before that ridge reached the Manila Trench, the western chain was the volcanic front. When the ridge reached the subduction zone at 5-4 Ma, its buoyancy temporarily interrupted the subduction thus causing a time gap in magmatic activity. Furthermore, this ridge-arc collision was probably also responsible for regional uplift causing extensive sub-aerial weathering and erosion as well as massive reef formation in the western chain. When subduction started again, the dip angle became shallower in response to the extra buoyancy of the downgoing ridge. If the depth of magma generation remained constant, the shallower dip angle would have naturally led to an eastward shift of the volcanic front thus producing the younger eastern chain. Moreover, we speculate that the abrupt change of the dip angle may have torn the downgoing slab thus allowing more enriched continental lithospheric material to invade the mantle wedge from the northwest, thus imprinting a geochemically more enriched signature on the magmas of the eastern chain.
\end{abstract}

Corresponding author. Tel.: 886-2-363-0231, ext. 2674x14. Fax: 886-2-363-6095. E-mail: tyyang@ccms.ntu.edu.tw.

Present address: Institut fur Geowissenschaften/Mineralogie. Saarstrasse. D-55099 Mainz. Germany. 


\section{Introduction}

The Taiwan-Luzon volcanic arc, generated in response to the subduction of the South China Sea Plate, collided with the eastern margin of the Eurasian Plate at the arc's southern and northern ends (e.g., Stephan et al., 1986; Suppe, 1988; Teng, 1990). As a consequence, volcanism ceased or was reduced to low levels in the proximity of the collision zones (Fig. 1). Systematic temporal and spatial variations in the geochemistry of the magmas erupted along the arc are ascribed to the involvement of subducted continent-derived sediments or crustal slivers close to the collision zones. However, the precise nature of these enriched components and the timing of their introduction into the source region are currently a matter of debate (Knittel et al., 1988; Chen et al., 1990; Defant et al., 1990; Juang and Chen, 1990; McDermott et al., 1993; Yang et al., 1995a).

The Taiwan-Luzon arc has been divided into five segments. These are the Taiwan, Bashi [the Babuyan segment of Defant et al. (1989), including the islands of Lutao, Lanyu and Hsiaolanyu], northern Luzon, Batan and Mindoro segments, respectively (Fig. 1; Defant et al., 1989). Previously the volcanology and geochemistry of the southern Bashi Segment (including Mt. Cagua volcano) and northern Luzon have been studied only by Richard et al. (1986), Jacques (1987) and McDermott et al. (1993). However, the geodynamic evolution of the arc, e.g., its segmentation, the distribution of the volcanic centers and the

Fig. 1. Schematic map showing the major tectonic features of the Taiwan-Luzon Arc considered to be related to the eastward subduction of the South China Sea Plate. Five volcanic segments can be recognized: (1) The Taiwan Segment; (2) The Bashi Segment; (3) The North Luzon Segment; (4) The Batan Segment; (5) The Mindoro Segment (Defant et al., 1989). The extinct mid-ocean ridge of the South China Sea Plate (Scarborough Seamount Chain) subducts below Luzon. The buoyant ridge is believed to be accreted to the overriding plate beneath Luzon and is causing the uplift of the fore-arc basin, which has been divided into the North Luzon Trough $(N L T)$ and West Luzon Trough (WLT) by the Stewart Bank (ST) and the Vigan High (VH) (Pautot and Rangin. 1989). The origin of the unusual triangular volcanic front at the north of Luzon will be discussed in the text. $C O B=$ continent-ocean boundary: $P F=$ Philippine Fault. $=$ extinct Miocene volcano; $\Delta=$ Quaternary volcano; $\star=$ active volcano. almost complete extinction of volcanism in the North Luzon Segment, located far from the collision zones, at about $4 \mathrm{Ma}$, is presently poorly understood.

In this paper, we identify a double arc structure in the Bashi Strait (Fig. 2). It consists of an older western volcanic chain and a younger eastern volcanic chain. We will argue that many features of the Bashi double arc structure, as well as the extinction of volcanism in the North Luzon Segment, can be best explained as the consequences of the subduction of the extinct spreading center of the South China Sea under the Taiwan-Luzon Arc.

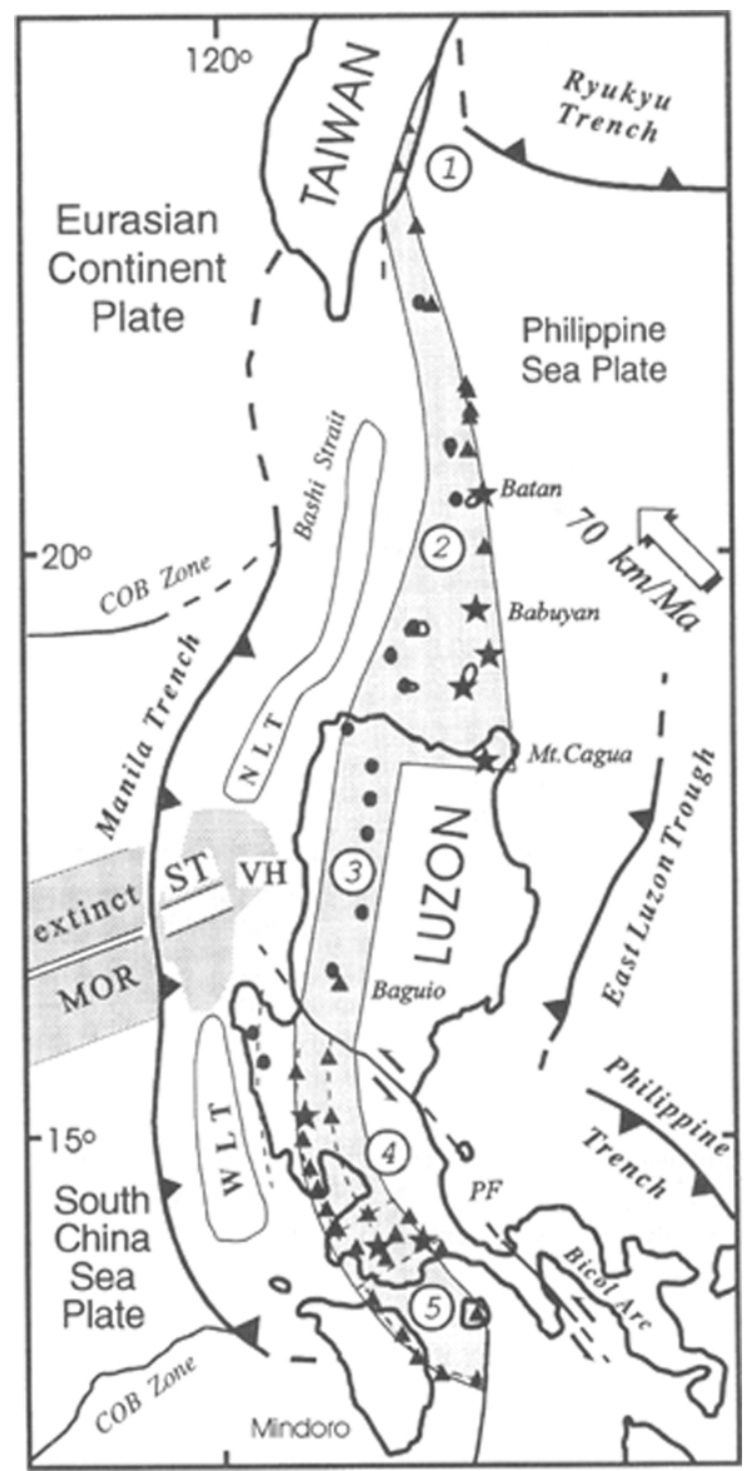




\section{Geologic setting}

A total of more than 22 volcanic islands is located in a triangular area between Taiwan and Luzon (Fig. 2). Together with Mt. Cagua on the northeastern tip of Luzon they form the Bashi Segment of the Taiwan-Luzon arc. Most islands are the tops of stratovolcanoes with near-vent facies, i.e., lava flows, dikes, craters, volcanic necks, cinder cones, breccias, tuffs and epiclastic deposits (Yang, 1992). The eruption products are mainly calc-alkaline andesites, although the compositional spectrum ranges from basalt to dacite (Jacques, 1987; Defant et al., 1990; Yang, 1992). Available radiometric data show that the volcanic arc has been active since Early Miocene times. Some volcanoes are still active and have historical eruption records (Alcaraz et al., 1956; Richard et al.. 1986: Jacques, 1987: Yang et al., 1995b), but others are characterized by very flat relief and are covered by limestone. Ultramafic xenoliths of mantle origin have been found on the Batan and Diogo islands (Richard et al.. 1986; Vidal et al.. 1989; Maury et al., 1992: Yang, 1992).

The North Luzon Segment comprises a few volcanic centers located in the North Luzon Central Cordillera, a mountain range that experienced significant Pliocene to Recent uplift $(>1000 \mathrm{~m}$ since the Late Miocene, e.g.. Christian, 1964). Most volcanoes, active between 10 and $4 \mathrm{Ma}$, are andesitic to dacitic in composition and are characterized by relatively low ${ }^{87} \mathrm{Sr} /{ }^{86} \mathrm{Sr}$ compared to other volcanics of the Taiwan-Luzon arc (Knittel et al., 1990; Defant et al.. 1990). The Scarborough Seamounts, an aseismic ridge west of northern Luzon, is thought to represent the extinct spreading center of the South China Sea and is presently being subducted below the arc (Taylor and Hayes, 1980, 1983; Hayes and Lewis. 1984: Pautot and Rangin, 1989).

\section{The Bashi double arc}

\subsection{Distribution of colcanoes}

Two volcanic chains, the Western Volcanic Chain (WVC) and the Eastern Volcanic Chain (EVC), can be identified in the Bashi Strait based on their geographic distribution. eruption ages, geomorphology and the geochemical signatures of the magmas (Fig. 2). The EVC comprises Lutao, Hsiaolanyu, Y'Ami, North, Mabudis, Siayan, Diogo, Batan (Mt. Iraya), Balintang, Babuyan, Didicas and Camiguin islands and Mt. Cagua from north to south (Fig. 2). Among these, Batan (Mt. Iraya), Babuyan. Didicas and Camiguin islands and Mt. Cagua are still active. The WVC consists of Lanyu. Itbayat, Batan (Mt. Matarem), Sabtang. Ibohos, Dequey, Panuitan and Calayan, Dalupiri and Fuga islands and extends toward northern Luzon. No active volcanism has been reported in this chain. The WVC and EVC are separated by about $50 \mathrm{~km}$ just north of Luzon $\left(18^{\circ} \mathrm{N}\right)$ and merge into a single volcanic chain near Batan island $\left(20^{\circ} \mathrm{N}\right)$.

\subsection{Age differences}

The EVC and WVC were constructed at different times. Table 1 summarizes the results of twelve new whole rock $\mathrm{K}$-Ar age determinations done on handpicked fresh chips several millimeters in size. These data were combined with previously reported ages (Richard et al., 1986; Jacques, 1987: Yang et al.. 1995b) and compiled in Table 2 where the characteristics of the EVC and WVC are compared. It is obvious from Table 2 and Fig. 2 that the magmatic activity in the WVC ceased at 4-2 Ma whereas the activity in the EVC is almost exclusively Quaternary. Apparently, the WVC was initially the active volcanic front of the arc. Volcanic activity stopped for an interval of about 4-2 Ma. then resumed further east forming the EVC. This shift did not take place gradually, otherwise volcanic centers would be distributed in the triangular area between 18 and $20^{\circ} \mathrm{N}$ instead of along two distinct chains. Even on the islets north of $20^{\circ} \mathrm{N}$, where younger volcanics seem to overlie older volcanic edifices, the youngest volcano is always located east of the older volcanic edifice. Examples are: Hsiaolanyu vs. Lanyu: Diogo vs. Itbayat; Mt. Iraya of Batan vs. Sabtang. Ibohos and Dequey islands. The precise age and exact composition of the EVC basement is unknown.

\subsection{Geomorphological contrast}

Geomorphologically, the WVC and EVC are distinct, reflecting their different histories. The volca- 
noes forming the EVC, all have well to partially preserved volcanic cones with steep slopes. In contrast, the volcanic islands of the WVC have rela- tively flat relief and exhibit well to partially developed laterites and terraces. The geomorphologic contrast between these two chains is evident in a com-

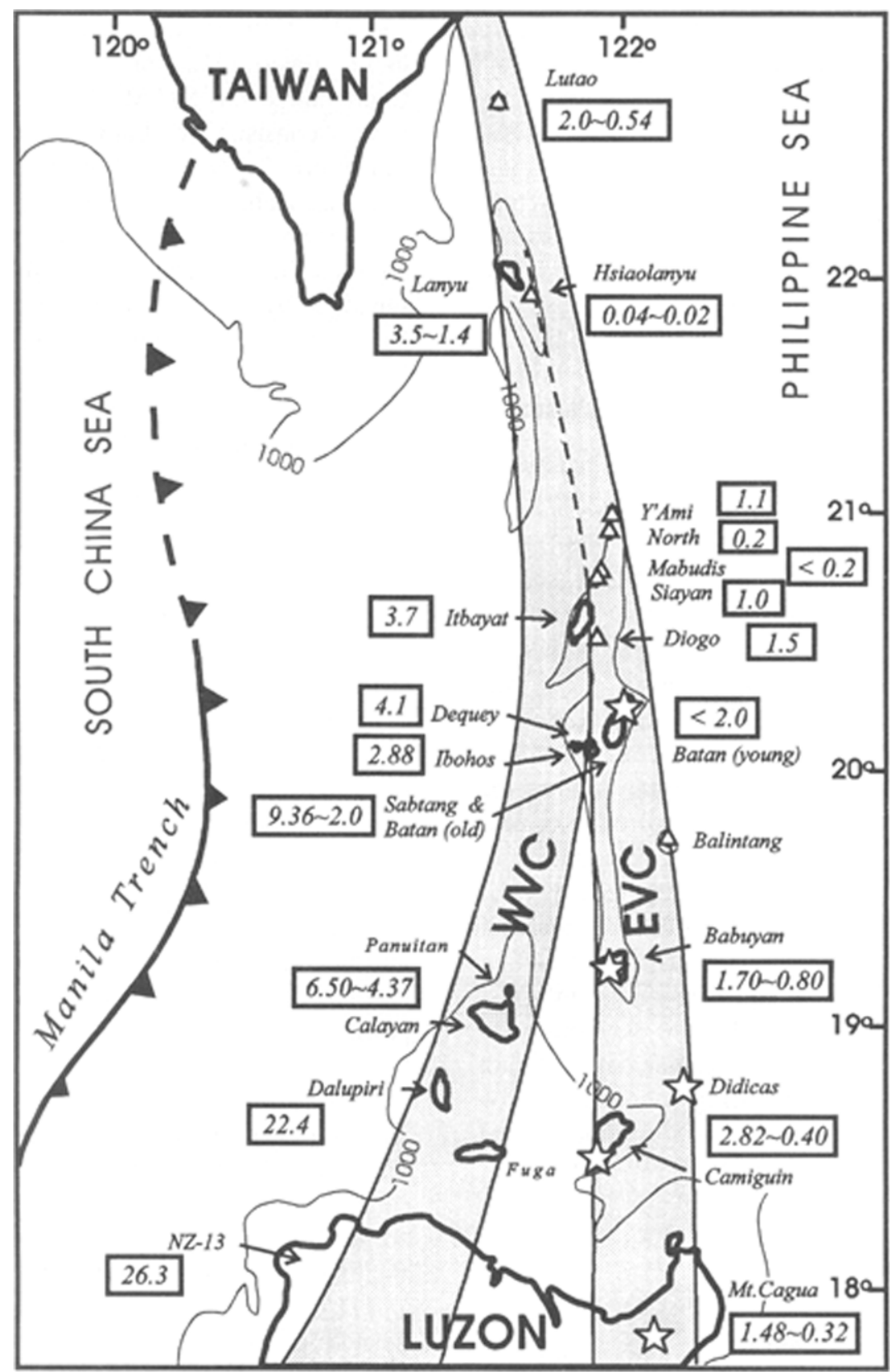

Fig. 2. Geographic distributions of volcanoes of the Bashi Segment and their radiometric ages. Two volcanic chains can be identified in the Bashi Segment of the Taiwan-Luzon Arc. They are separated in the south by $50 \mathrm{~km}$, and converge at about $20^{\circ} \mathrm{N}$. The numbers shown in the boxes are the radiometric ages (Ma) of representative lavas. Note that all the Quaternary volcanoes, some of which are still active, are located in the East Volcanic Chain $(E V C)$. No active volcanoes are known to be present in the $W V C$. $k=$ active volcano; $\Delta=$ extinct Quaternary volcano. 
parison of the highest peaks at the same latitude. Diogo island $\left(574 \mathrm{~m} ; \sim 3 \mathrm{~km}^{2}\right)$ vs. Itbayat island $\left(277 \mathrm{~m}: \sim 75 \mathrm{~km}^{2}\right)$ is a good example. The other examples are Mt. Iraya of Batan island vs. Sabtang, Ibohos and Dequey islands; Babuyan and Camiguin islands vs. Calayan, Dalupiri, Irao and Fuga islands (Table 2). Furthermore. all islands of the WVC are covered by thick massive limestone, implying that the volcanoes of the WVC were initially below sea level and were subsequently uplifted. Erosion and weathering produced the laterites and terraces.

\subsection{Geochemical variations}

Extreme geochemical variations in the Bashi double arc have been documented by several studies (Defant et al.. 1990; Chen et al., 1990; Yang, 1992; McDermott et al., 1993). In addition to along-strike variations. Jacques (1987) and Yang (1992) also observed significant variations across the arc. In as much as the eastward shift of volcanism represents a time sequence, the across-arc variations may reflect variations of the magma sources in time. The geochemical characteristics of representative lavas from the WVC and EVC are compared in Table 3 and Fig. 3. There is only limited variation in ${ }^{87} \mathrm{Sr} /{ }^{* 6} \mathrm{Sr}$ ratios, but the EVC lavas have enriched geochemical signatures, i.e.. lower $\epsilon_{\mathrm{Nd}}$ and higher $K_{\mathrm{Si}}$. $(\mathrm{La})_{\mathrm{n}}$ and $(\mathrm{La} / \mathrm{Yb})_{n}$ values, relative to the WVC at similar latitude. The distinct geochemical characteristics between lavas from the EVC and WVC suggests that either the EVC and WVC tap different reservoirs or that an enriched component has been introduced into the source region at about $2 \mathrm{Ma}$.

Some lavas. mainly those from Batan and Babuyan, exhibil unusual $\mathrm{Sr}-\mathrm{Nd}$ isotopic signatures.

Table 1

$\mathrm{K}$-Ar dating results of northern Taiwan-Luzon Arc volcanics in this study

\begin{tabular}{|c|c|c|c|c|c|c|}
\hline Locality & Sample number & Rock type & $\begin{array}{l}\text { Age } \\
(\mathrm{Ma} \pm 1 \sigma)\end{array}$ & $\begin{array}{l}{ }^{+1)} \mathrm{Ar} \\
(10 \quad \operatorname{ccs} \mathrm{STP} / \mathrm{g})\end{array}$ & $\begin{array}{l}{ }^{+01} \mathrm{Ar} \\
(\%)\end{array}$ & $\begin{array}{l}\mathrm{K} \\
(\%)\end{array}$ \\
\hline \multirow[t]{3}{*}{ Y'Ami I. } & YAMI-0I & basalt & $0.9 \pm 0.5$ & 0.002 & 5.2 & 0.60 \\
\hline & & & & 0.002 & 5.7 & 0.59 \\
\hline & & & $1.07 \pm 0.20$ & 0.0025 & 9.2 & 0.60 \\
\hline \multirow[t]{2}{*}{ North I. } & NT-(01 & dacite & $0.2 \pm 0.1$ & 0.001 & 0.6 & $1 .+4$ \\
\hline & & & & 0.001 & 11.8 & $1 .+3$ \\
\hline \multirow[t]{2}{*}{ Mabudis I. } & MBDS-0 1 & andesite & $<0.2$ & $<0.001$ & $<1$ & 1.35 \\
\hline & & & & $<0.001$ & $<1$ & 1.35 \\
\hline \multirow[t]{2}{*}{ Siayan 1.} & SAY-0) & andesite & $1.0 \pm 0.2$ & 0.004 & 128 & 1.11 \\
\hline & & & & 0.004 & 11.9 & 1.13 \\
\hline Diogo I. & $D G-()]$ & andesite & $1.5 \pm 0.1^{h}$ & 0.009 & 5.1 & 1.54 \\
\hline \multirow[t]{3}{*}{ Ithayat 1.} & [BYT-0] & andesite & $3.5 \pm 0.5$ & 0.007 & 21.1 & 0.58 \\
\hline & & & & 0.008 & 19.0 & 0.58 \\
\hline & & & $3.73 \pm 0.27$ & 0.0088 & 20.0 & 0.61 \\
\hline \multirow[t]{2}{*}{ Sabtang 1 . } & SBT-02 & andesite & $2.03 \pm 0.16$ & 0.006 & 32.6 & 0.78 \\
\hline & & & & 0.005 & 27.9 & 0.80 \\
\hline \multirow[t]{2}{*}{ Ibohos I. } & IBHS-0IE & andesite & $2.88 \pm 0.26$ & 0.008 & 25.5 & 0.75 \\
\hline & & & & 0.008 & 28.3 & 0.75 \\
\hline \multirow[t]{2}{*}{ Dequey I. } & DQY-0I & andesite & $4.1 \pm 0.2$ & 0.015 & 42.9 & 0.91 \\
\hline & & & & 0.014 & 40.4 & 0.91 \\
\hline \multirow[t]{2}{*}{ Dilupiri 1.} & DILPR-(1)IA & andesite & $22.4 \pm 1.1$ & 0.031 & 53.7 & 0.36 \\
\hline & & & & 0.032 & 54.8 & 0.36 \\
\hline N. Luzon & $\mathrm{NZ}-13$ & andesite & $26.3 \pm 1.9^{b}$ & 0.094 & 63.8 & 0.92 \\
\hline
\end{tabular}

The analyses were performed at the commercial Teledyne Isotopes Geochemistry laboratory and Institute of Geology. Academic Sinica. Beijing. Sample MBDS-0I is too young to generate enough ${ }^{41)} \mathrm{Ar}$ to be detected. Two samples (YAMI-01 and IBYT-01) were sent 10 Okayama Iniv.. Japan for cross-check. These show better precision and are consistent with the commercial dating results. Therefore, we are confident the data accurately date the ages of the volcanics in this study.

"The analysis was performed at Okayama University, Japan on the same rock sample.

"The analy vis was performed at Academia Sinica. Beijing, People's Republic of China. 
plotting below the mantle array (Vidal et al., 1989; Chen et al., 1990; McDermott et al., 1993; Yang et al., 1995a). This signature is unique for arc lavas. which tend to plot above the mantle array and, hence, is difficult to explain by a simple subducted sediment-depleted mantle mixing model. McDermott and his co-workers proposed an unusual composition of the "subduction component" to account for the unique geochemical variation. However, they can not explain why this unusual component only occurred after $2 \mathrm{Ma}$ and why it is found only near Batan and Babuyan islands.

Chen et al. (1990) and Yang et al. (1995a) argued for the involvement of an enriched mantle (EM) component, considered to reside in the continental lithospheric mantle. Nevertheless, how the EM component was introduced from the sub-Eurasian plate into the mantle wedge of the Taiwan-Luzon Arc is an unresolved problem.

\subsection{Geophysical mapping of the subducting plate}

Although Cardwell et al. (1980), Lin and Tsai (1981) and Hamburger et al. (1983) have synthesized the seismicity and focal mechanisms for the complex zones of plate convergence from Taiwan to Luzon, the detailed geometry of the subducting plate beneath the Taiwan-Luzon Arc is not well known. In order to improve the resolution of the BenioffWadati zone in the Taiwan-Luzon Arc, we have compiled the updated seismic data for this area. Earthquakes located by worldwide seismic networks were used to examine the spatial pattern of seismicity in the Taiwan-Luzon region. The data used in

Table 2

Summary of the geomorphologic characteristics of northern Taiwan-Luzon Arc volcanic chains

\begin{tabular}{|c|c|c|c|c|c|c|c|c|}
\hline $\begin{array}{l}\text { West Volcanic } \\
\text { Chain }\end{array}$ & Terraces $^{a}$ & Laterite ${ }^{a}$ & Limestone & $\begin{array}{l}\text { Eruption ages } \\
(\mathrm{Ma})^{r}\end{array}$ & $\begin{array}{l}\text { Highest } \\
\text { peak }(\mathrm{m})\end{array}$ & $\begin{array}{l}\text { Volcano } \\
\text { shape }^{h}\end{array}$ & $\begin{array}{l}\text { Magmatic } \\
\text { activity }\end{array}$ & $\begin{array}{l}\text { East Volcanic } \\
\text { Chain }\end{array}$ \\
\hline & $\sqrt{ }$ & $v^{\prime}$ & $\sqrt{\prime}$ & $2.0-0.54$ & 281 & $\Delta$ & $\Delta$ & Lutao \\
\hline \multirow[t]{6}{*}{ Lanyu } & y & $\sqrt{ }$ & i & $3.5-1.4$ & 582 & $\Delta$ & - & \\
\hline & - & - & - & $0.04-0.02$ & 116 & $\sqrt{ }$ & $\Delta$ & Hsiaolanyu \\
\hline & - & - & - & 1.1 & 211 & $v^{i}$ & $\Delta$ & $\mathrm{Y}^{\prime} \mathrm{Ami}$ \\
\hline & - & - & - & 0.2 & 263 & i & $\Delta$ & North \\
\hline & - & - & - & $<0.2$ & 254 & $\sqrt{ }$ & $\Delta$ & Mabudis \\
\hline & - & - & - & 1.0 & 164 & i & $\Delta$ & Siayan \\
\hline \multirow[t]{3}{*}{ Itbayat } & $v^{\prime}$ & r & $\sqrt{\prime}$ & 3.7 & 277 & - & - & \\
\hline & - & - & - & 1.5 & 574 & $v^{i}$ & 1 & Diogo \\
\hline & - & - & - & $<2.0$ & 1009 & $\sqrt{i}$ & $\sqrt{ }$ & Batan-Y \\
\hline Batan- $\mathrm{O}^{\mathrm{e}}$ & $\Delta$ & $\Delta$ & $\sqrt{ }$ & $9.4-2.3$ & 450 & $\Delta$ & - & \\
\hline Sabtang & $\sqrt{ }$ & $\sqrt{ }$ & $\sqrt{ }$ & 2.03 & 347 & \lrcorner & - & \\
\hline Ibohos & $\Delta$ & $\Delta$ & $\sqrt{ }$ & 2.88 & 107 & - & - & \\
\hline \multirow[t]{2}{*}{ Dequey } & $\Delta$ & $\Delta$ & $\sqrt{ }$ & 4.1 & 62 & - & - & \\
\hline & - & - & - & $1.70-0.80$ & 963 & i & r & Babuyan \\
\hline \multirow[t]{2}{*}{ Calayan } & $\sqrt{ }$ & $\Delta$ & $\sqrt{ }$ & $6.50-4.37$ & 499 & $\Delta$ & - & \\
\hline & - & - & - & $<1952 \mathrm{AD}$ & 82 & i & $\sqrt{ }$ & Didicas \\
\hline \multirow[t]{2}{*}{ Dalupiri } & $\sqrt{ }$ & $\sqrt{ }$ & v & 22.4 & 296 & - & - & \\
\hline & $\Delta$ & - & $\Delta$ & $2.82-0.40$ & 828 & $\sqrt{ }$ & r & Camiguin \\
\hline Irao & $\Delta$ & $\Delta$ & $\sqrt{ }$ & $?$ & 25 & - & - & \\
\hline \multirow[t]{2}{*}{ Fuga } & $\sqrt{ }$ & $\sqrt{ }$ & $\sqrt{ }$ & $?$ & 208 & - & - & \\
\hline & - & - & - & $1.48-0.32$ & 1160 & $\sqrt{ }$ & $\sqrt{ }$ & Mt. Cagua \\
\hline
\end{tabular}

${ }^{a} \sqrt{ }=$ well developed; $\Delta=$ partially developed; $-=$ none.

${ }^{\mathrm{b}} \sqrt{ }=$ well preserved; $\Delta=$ partially preserved; - = poorly preserved.

c $\sqrt{ }=$ active volcano; $\Delta=$ Quaternary volcano; $-=$ extinct Miocene volcano.

d younger magmatism of Batan Island, represented by Mt. Iraya located at the northeastern part of the island.

" older magmatism of Batan Island, mainly distributed in the central and southern parts of the island.

$f$ data from this study; Richard et al. (1986); Jacques (1987); Defant et al. (1990); Yang et al. (1995b). 
this study, listed in the Preliminary Determination of Epicenters (PDE) catalog, are earthquakes that occurred between 1967 and $1994\left(M_{\triangleleft} \geq 4\right)$. The 90\% marginal confidence interval on depth and the geometric mean of the semi-major and semi-minor axes of horizontal $90 \%$ confidence ellipse are less than or equal to $8.5 \mathrm{~km}$. The hypocentral projections of earthquakes along the $\mathrm{E}-\mathrm{W}$ cross sections are shown in Fig. 4.

The seismicity extends to about $300 \mathrm{~km}$ depth in the southern part of the $\operatorname{arc}\left(13-15^{\circ} \mathrm{N}\right)$. A continuous eastward subducting plate is clearly observed along the Manila Trench and its northward extension. The dip of the Benioff zone steepens to near vertical at both ends of the subduction zone due to arc-continent collision where the continental crust resists subduction. The shallowest subduction angle is observed at the latitude where the extinct spreading ridge subducts $\left(\mathrm{ca} .17^{\circ} \mathrm{N}\right)$. The dip angle decreases from the south $\left(\sim 90^{\circ}\right.$ at $\left.\sim 13^{\circ} \mathrm{N}\right)$ towards the central part of the arc segment $\left(\sim 30^{\circ}\right.$ at $\left.16-18^{\circ} \mathrm{N}\right)$. In the north. however, the subducting slab dips relatively steeply $\left(\sim 80^{\circ}\right.$ at $\sim 22^{\circ} \mathrm{N}$ and $\sim 70^{\circ}$ at $\sim$ $20^{\circ} \mathrm{N}$ ) suggesting the presence of a discontinuity exists at about $19-20^{\circ} \mathrm{N}$ (Fig. 4). This discontinuity is probably located at the transition zone between the continental crust of the Eurasian Plate and the oceanic crust of the South China Sea (Taylor and Hayes. 1983). The westward subduction is observed at $12-$ $14^{\circ} \mathrm{N}$ and $16-18^{\circ} \mathrm{N}$, related to the Philippine Trench and Luzon Trough subduction system, respectively (Fig. 1). These westward subduction systems are

Table 3

Geochemical characteristics of the West and East volcanic chains comparing representative lavas from similar latitude

\begin{tabular}{|c|c|c|c|c|c|c|c|c|c|}
\hline WVC & Spl. No. & Age (Ma) & ${ }^{87} \mathrm{Sr} /{ }^{86} \mathrm{Sr}$ & $\epsilon_{\mathrm{Vd}}$ & $K_{\mathrm{Si}}{ }^{a}$ & $(\mathrm{La})_{n}$ & $(\mathrm{La} / \mathrm{Yb})_{n}$ & Spl. No. & EVC \\
\hline \multicolumn{10}{|l|}{$\sim 22^{\circ} \mathrm{N}$} \\
\hline \multirow[t]{2}{*}{ Lanyu } & LY4-03 & 1.9 & 0.70569 & +1.4 & 2.29 & 30.8 & 4.0 & & \\
\hline & & 0.04 & 0.70479 & -0.3 & 7.52 & 145.7 & 15.3 & SLY-01 & Hsiaolanyu \\
\hline \multicolumn{10}{|l|}{$-20.5 \mathrm{~N}$} \\
\hline \multirow[t]{2}{*}{ Itbayat } & IBYT-0| & 3.7 & 0.70429 & +3.1 & 4.56 & 32.7 & 3.8 & & \\
\hline & & 1.5 & 0.70395 & -0.1 & 9.73 & 89.2 & 13.3 & DG-01 & Diogo \\
\hline \multicolumn{10}{|l|}{$-20^{\circ} \mathrm{N}$} \\
\hline & & $<0.1$ & 0.70479 & -2.7 & 14.9 & 121.6 & 13.8 & BIE & Batan- $Y^{h}$ \\
\hline Batan-0) & BTN-3 & 4.59 & 0.70424 & +2.3 & 4.86 & 45.4 & 4.8 & & \\
\hline Sablang & SBT- -02 & 2.03 & 0.70406 & +2.2 & 6.03 & 36.5 & 4.6 & & \\
\hline Ibohos & IBHS-0|E & 2.88 & 0.70430 & +0.8 & 4.31 & 4.3 .5 & 2.9 & & \\
\hline Dequey & DQY -01 & 4.10 & 0.70457 & +2.0 & 5.33 & 82.9 & 7.0 & & \\
\hline \multicolumn{10}{|c|}{$18.5-19.2 \mathrm{~N}$} \\
\hline & & $0.83^{\circ}$ & 0.70449 & -0.7 & 7.96 & 55.2 & 6.1 & BBY-1A & Babuyan \\
\hline Calayan & CLY-09 & $6.68^{\circ}$ & 0.70377 & +6.3 & 0.88 & 6.9 & 1.1 & & \\
\hline \multirow[t]{3}{*}{ Dalupiri } & DLPR-1A & 22.4 & 0.70373 & +9.2 & 2.00 & 9.1 & 0.8 & & \\
\hline & & $<1952 \mathrm{AD}$ & 0.70462 & -0.5 & 8.45 & 136.2 & 18.9 & DDC-01 & Didicas \\
\hline & & $0.40^{\circ}$ & 0.70354 & +2.8 & 5.93 & 37.5 & 4.1 & $\mathrm{CMG}-1 \mathrm{~A}$ & Camiguin \\
\hline \multicolumn{10}{|l|}{$\sim 18^{\circ} \mathrm{N}$} \\
\hline \multirow[t]{2}{*}{ N. Luzon } & $N Z-13$ & 26.3 & 0.70321 & +7.4 & 5.69 & 19.0 & 4.1 & & \\
\hline & & 1.27 & 0.70386 & +4.3 & 10.2 & 36.8 & 4.4 & $\mathrm{Ca} 2$ & Mt. Cagua ${ }^{h}$ \\
\hline
\end{tabular}

Chemical data from Yang (1992) and Yang et al. (1994. 1995a).

${ }^{a} K_{\mathrm{Si}}=100 \times \mathrm{K}_{2} \mathrm{O} \% /\left(\mathrm{SiO}_{2} \%-40\right)$; definition after Wheller et al. (1987).

'Data from McDermott et al. (1993).

"Data from Jacques (1987). 


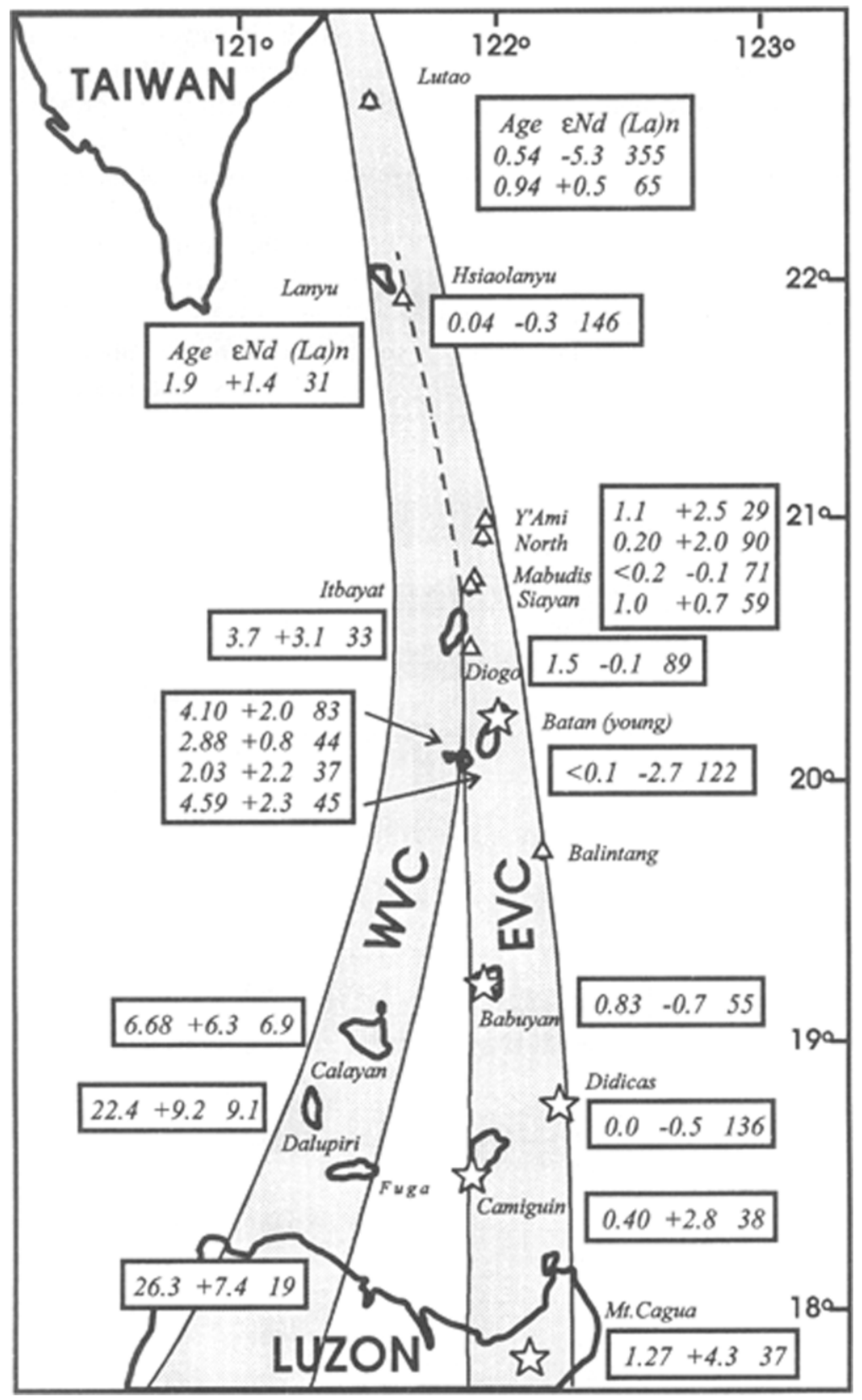

Fig. 3. $\epsilon_{\mathrm{Vd}}$ and (La) variations of representative lavas along the Bashi Segment of the Taiwan-Luzon Arc. It is clear that the lavas from the East Volcanic Chain exhibit more enriched geochemical signatures, i.e., lower $\epsilon_{\mathrm{N} d}$ and higher (La) ${ }_{\mathrm{n}}$ values, than those from the West Volcanic Chain at the same latitude. This implies that an enriched component was present in the source region of the arc after 2 Ma. Data from Table 3 and Yang et al. (1994). Symbols same as Fig. 2. 

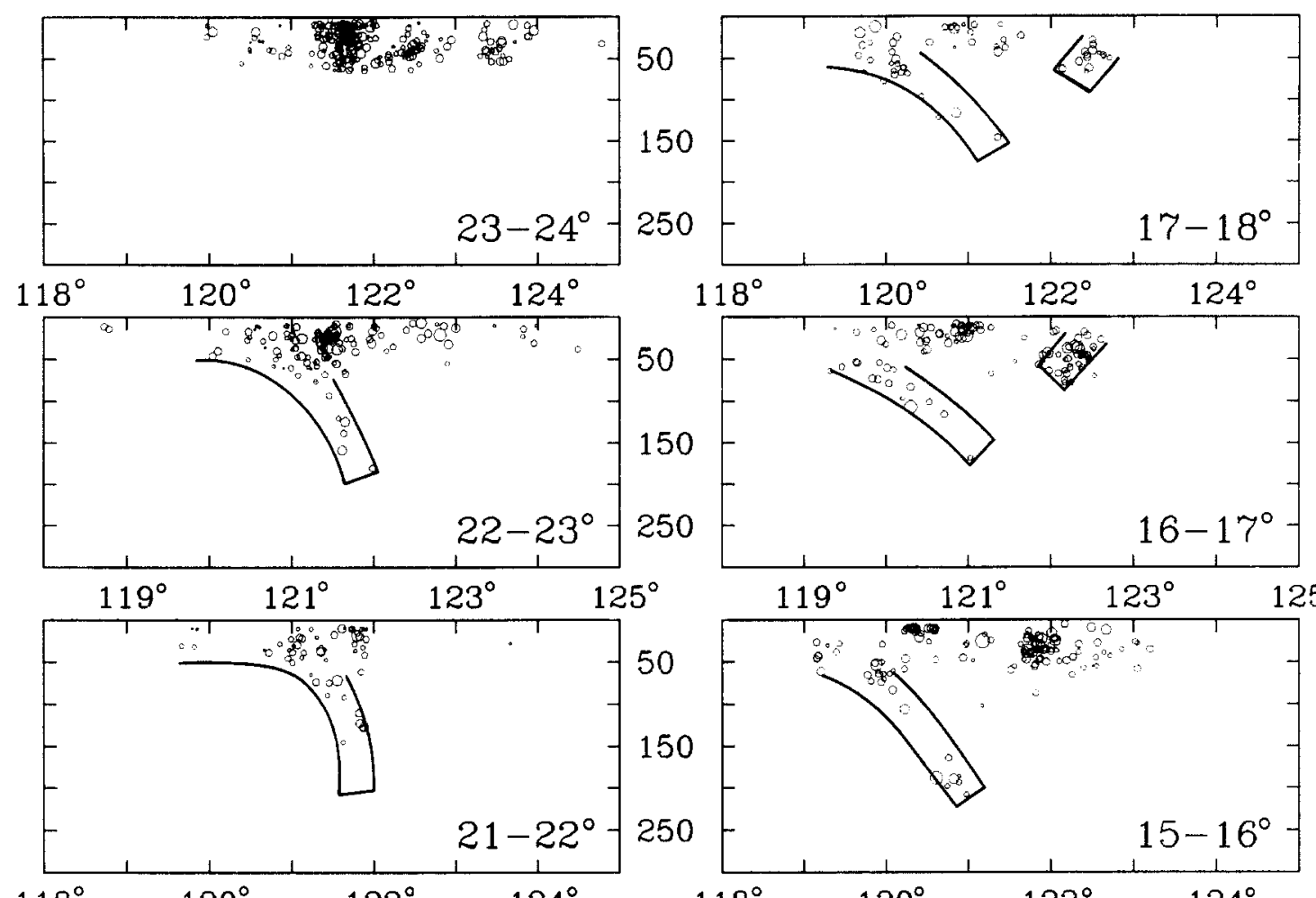
$125^{\circ}$
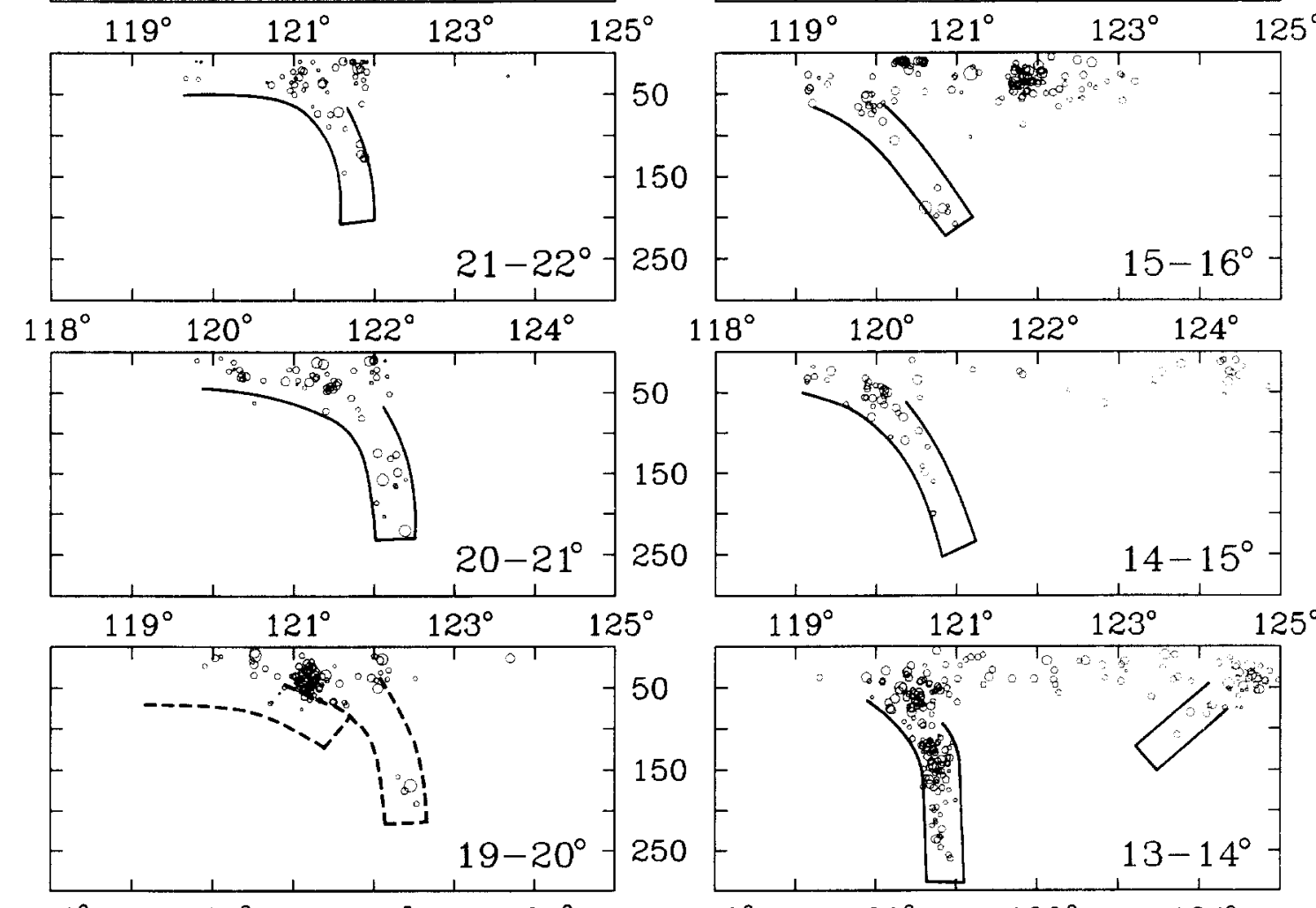

$18^{\circ} \quad 120^{\circ} \quad 122^{\circ} \quad 124^{\circ}$
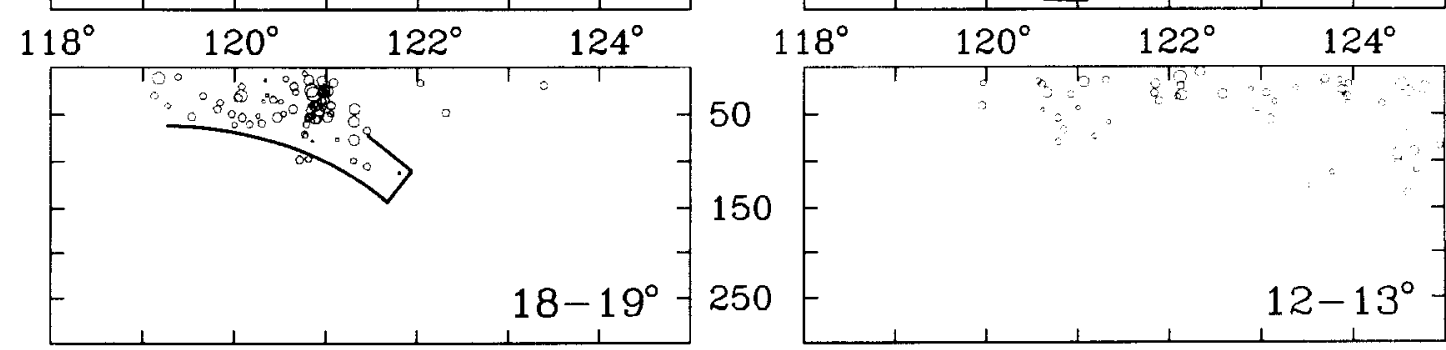

Fig. 4. The projections of earthquake epicenters $\left(M_{\checkmark} \geq 4\right)$ in the Taiwan-Philippines region (1967-1994) for each degree of latitude. The Benioff zones are arbitrarily defined as $\sim 50 \mathrm{~km}$ thick of subducting plate. 
believed to be not related to the generation of the Taiwan-Luzon Arc and are beyond the scope of this paper.

\section{The ridge subduction model}

\subsection{An analogous double arc in the Lesser Antilles Arc}

The tectonic history of the northern part of the Taiwan-Luzon Arc seems to resemble that of the Lesser Antilles Arc where a similar double arc structure exists. Thus the models developed in that region may be relevant for the present study. The Lesser Antilles island arc has experienced a complex history since its birth in the Early Cretaceous. Volcanism of the Older arc began in the Early Eocene on a Mesozoic arc substratum. This volcanic activity later ceased, and resumed after several million years along the Recent arc, which is still active. These two ares are imbricated in the south and diverge northward, where they are separated by a $50 \mathrm{~km}$ wide corridor. Bouysse and Westercamp (1990) argued that a buoyant ridge reached the trench, stopped the subduction and induced dramatic local uplift in the Late Oligocene. After a gap of 9-10 m.y., the volcanic activity resumed along the Recent arc with a westward jump relative to the Older arc (Bouysse and Westercamp, 1990).

\subsection{Effects of the ridge subduction}

Subduction of a ridge may trigger several responses in arc-trench systems. The extra buoyancy of the ridge is believed to give the plate greater resistance against subduction. This effect tends to break the continuity of the subducted plate, thus affecting the morphology, seismicity and magmatism of the arc-trench system (Vogt, 1973; Kelleher and
McCann, 1976; Vogt et al.. 1976; Nur and BenAvraham, 1983, 1989; McCann and Sykes, 1984; McGeary et al., 1985: Cloos, 1993).

Since an extinct mid-ocean ridge is currently subducting below northern Luzon (Pautot and Rangin, 1989), it is worthwhile to investigate whether this process may account for the observations in the northern part of the Taiwan-Luzon Arc. Several unusual features, discussed above, may be attributed to the subduction of the aseismic Scarborough Seamount chain: (1) the fore-arc basin (Luzon Trough) is interrupted in front of the ridge by a broad structural high (Stewart Bank and Vigan High), which divides the basin into two subbasins, the West Luzon Trough and the North Luzon Trough (Fig. 1; Lewis and Hayes, 1983; Pautot and Rangin, 1989). It is inferred that the buoyant ridge has been accreted to the upper plate. (2) It seems that the seismicity is reduced to a lower level where the ridge is being subducted (e.g.. Hamburger et al., 1983; Hayes and Lewis, 1984; Cheng and Yeh, 1991). Although many examples of reduced seismicity due to ridge subduction have been documented (e.g., Tonga-Kermadec, Aleutian, Mariana, Sunda-Banda, and Andes arcs), the mechanism is still not clear (Vogt et al., 1976; Kelleher and McCann, 1976). (3) There is an obvious volcanic gap [for possible exceptions see Alvir (1956) and Ringenbach et al. (1993)] extending for ca. $220 \mathrm{~km}$ from Mt. Cagua to Baguio in northern Luzon, which separates the Quaternary volcanoes of the Taiwan-Luzon Arc into two segments (Fig. 1). It is believed that the discontinuity of the subducting plate due to buoyant ridge collision may cause a temporal volcanic gap (Nur and Ben-Avraham. 1989).

\subsection{Geodynamic model}

In analogy to the case in the Lesser Antilles Arc and taking into consideration the possible effects of

\footnotetext{
Fig. 5. Geodynamic model of the northern Taiwan-Luzon Arc. Stage I ( $>6 \mathrm{Ma}$ ): The Western Volcanic Chain, a typical intra-oceanic are, was formed. Stage II (5-4 Ma): The Scarborough Seamount Chain was attached beneath the upper plate and resisted subduction. Arc magmatism ceased at the ridge-arc intersection. The northern part of the Taiwan-Luzon Arc was colliding with the Eurasian Plate, proto-Taiwan was formed at this time. Stage III $(<2 \mathrm{Ma})$ : The ridge began to subduct and the subduction angle was shallower than before due to the greater buoyancy of the ridge. The Eastern Volcanic Chain was formed at this time. The subducting plate was broken around the plate boundary between the Eurasian Plate and South China Sea Plate. The EM component was introduced into the mantle wedge of the Taiwan-Luzon Arc enriching the magma source.
} 


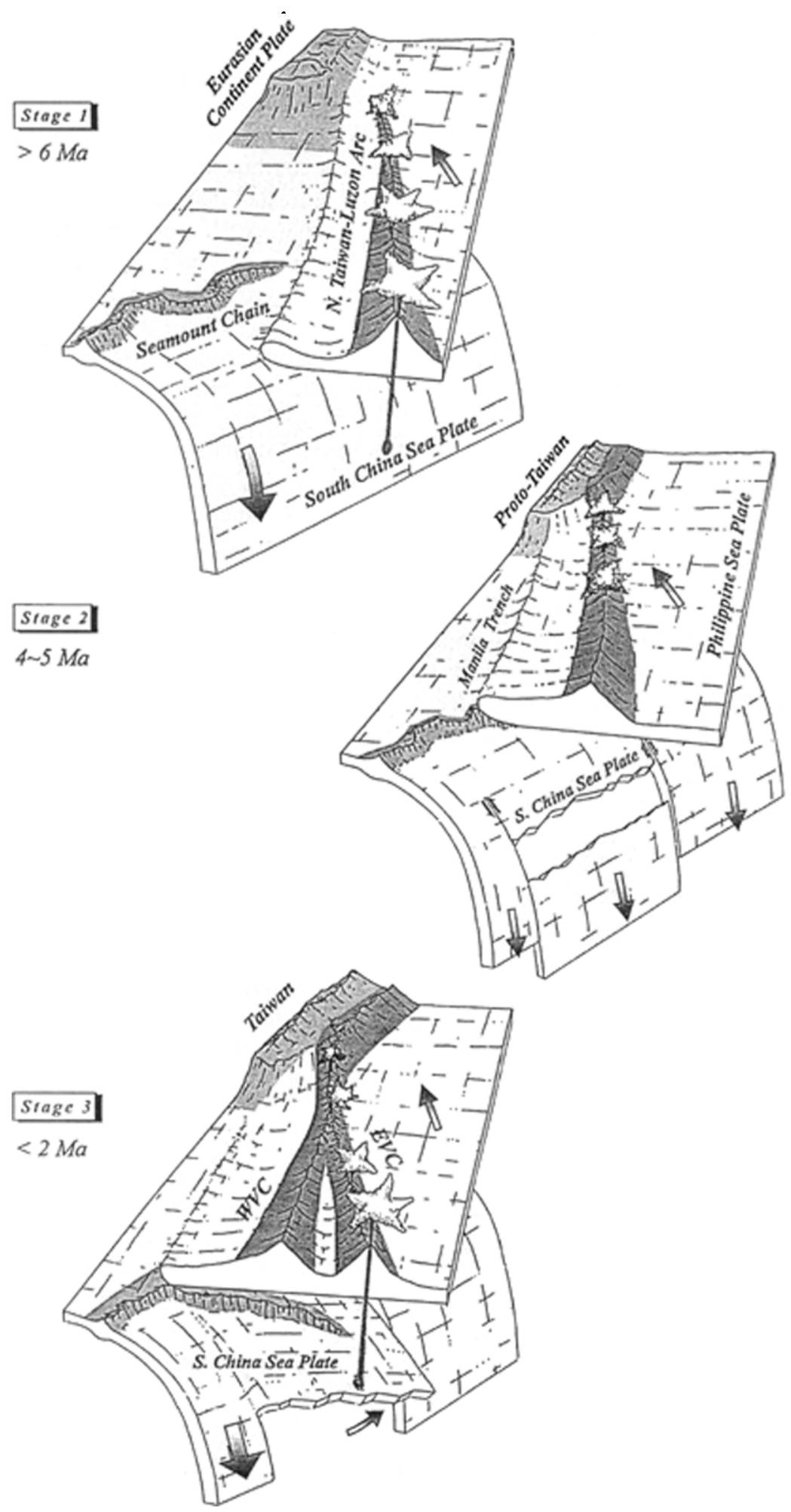


the Scarborough Seamount Chain subduction, we propose a geodynamic model (Fig. 5) to account for the magmatic evolution of the northern part of the Taiwan-Luzon Arc.

\subsubsection{Stage $1(>6 \mathrm{Ma})$}

The Western Volcanic Chain of the TaiwanLuzon Arc, at this time a typical intra-oceanic island arc, was formed in the Early Miocene in response to the eastward subduction of the South China Sea below the Philippine Sea Plate. The Taiwan-Luzon Arc was approaching the margin of the Eurasian Plate due to the northwestward movement of the Philippine Sea Plate (Seno and Kurita, 1978). The extinct ridge of the South China Sea, the Scarborough Seamount Chain, had probably not reached the arc during this stage.

\subsubsection{Stage II (5-4 Ma)}

The extinct ridge reached the arc. The ridge, due to its greater buoyancy, resisted the downgoing movement into the mantle and was accreted to the upper plate and uplifted the fore-arc basin. Underplating may have disconnected the eruption centers in North Luzon from their sources in the mantle wedge, resulting in a temporary cessation of volcanism in the collision zone. Meanwhile, the northern part of Taiwan-Luzon Arc collided with the Eurasian Plate, thus the arc volcanism ceased at the northern end due to the arc-continent collision. Rapid uplift is recorded in the Taiwan Segment during this stage (Liew et al., 1990; Liu and Yu, 1990; Chen and Liu, 1992; Chen and Liu, 1993). Abundant continent-derived sediments were subducted beneath the arc, resulting in enrichment of the source region of the arc magmas. Consequently, the arc volcanics near the collision zone obtained more enriched geochemical signatures (Lo, 1989; Defant et al., 1989, 1990; McDermott et al., 1993; Fourcade et al., 1994; Yang et al., 1994).

\subsubsection{Stage III $(<2 \mathrm{Ma})$}

After a period of resisting downward movement, resulting in the transfer of part of the ridge complex to the upper plate, the pull of the subducting plate and the relative compressive movement between the upper and subducting plate finally forced the extinct spreading ridge to resume subduction. However, the dip angle of the subducting plate was less steep than before because of the greater buoyancy resulting from the low density of the young and thick ridge. The Eastern Volcanic Chain formed east of the WVC as a result of the decreased subduction angle. Near the boundary between the continental crust of the Eurasian Plate and the oceanic crust of the South China Sea Plate, the subducting plate was broken (as already suggested by Jacques, 1987) by the uplifting force of the buoyant ridge. Evidence for this disruption is the abrupt change in the inclination of the subduction zone at about $19-20^{\circ} \mathrm{N}$ (Fig. 4). An enriched mantle component, which is believed to have resided in the lithospheric mantle of the Eurasian Plate (Tatsumoto and Nakamura, 1991: Tu et al.. 1991, 1992: Chung et al., 1995), thus might have been introduced into the mantle wedge through that tear in the subducting plate.

\section{Discussion}

\subsection{The assumptions of the model}

The ridge subduction model not only explains the geological evolution of the Taiwan-Luzon Arc, especially the volcanic gap and the eastward shift of volcanic front, but also provides a possible mechanism for the enrichment of the mantle wedge beneath the Taiwan-Luzon Arc. However, this model is based on the following assumptions: (1) the magma was generated at about constant depth below the overriding plate at about $110 \mathrm{~km}$ depth (Tatsumi et al., 1986); (2) the buoyancy of the ridge was large enough to decrease the dip angle of the subducting plate.

The first assumption can be verified by inspection of the distribution of earthquake epicenters and volcanoes in this area. All Quaternary and active volcanoes lie about $110 \mathrm{~km}$ above the Benioff zone (Fig. 4; Lin and Tsai, 1981). In addition, no near-trench high-magnesium andesites are found in this area, implying that the lavas of the Taiwan-Luzon Arc are normal arc magmas generated at "normal" depths above the subducting plate.

Although the extinct mid-ocean ridge of the South China Sea Plate is young enough to be hot and buoyant, the second assumption is not easily substan- 
tiated due to the lack of heat flow data on the ridge. However, it is well accepted that a ridge having thicker crust has less density and greater buoyancy relative to the neighboring oceanic plate (Detrick and Watts. 1979; Cloos, 1993). In addition, higher heatflow values $(>100 \mathrm{~mW})$ are found for the central part of the South China Sea (Taylor and Hayes, 1983). The uplift of the fore-arc basin by the subduction of the Scarborough Seamount Chain (Fig. 1; Pautot and Rangin. 1989) and the uplift experienced by the Central Cordillera of northern Luzon also supports the conclusion that the ridge has a greater buoyancy than the South China Sea crust. Furthermore, the inclination of the Benioff zone decreases where the ridge intersects the arc, compared to the collision zones at both ends of the Taiwan-Luzon Arc (cf.. Figs. 1 and 4). Therefore, we can reasonably conclude that the Scarborough Seamount Chain has a buoyancy large enough to decrease the inclination of the subducting plate. Meanwhile, the dip angles of the Benioff zone are not consistent around $19-20^{\circ} \mathrm{N}$ (Fig. 4), east of the continent-ocean boundary zone (Taylor and Hayes, 1983). This agrees with our model that the subducted plate may have been recently torn at the plate boundary. This tear in the plate may have provided a pathway for the introduction of an "exotic" mantle component residing in the subcratonic lithosphere into the mantle wedge that Chen et al. (1990) and Yang et al. (1995a) considered to be responsible for the unusual low ${ }^{1+3} \mathrm{Nd} /{ }^{144} \mathrm{Nd}$ for a given ${ }^{87} \mathrm{Sr} /{ }^{86} \mathrm{Sr}$ isotopic composition. Evidence for this assumption is that the unusual isotopic signature is observed only between about 19 and $20^{\circ} \mathrm{N}$ (Yang. 1992; McDermott et al.. 1993).

\subsection{Mechanism of uplift}

There are many factors controlling the formation of marine terraces, e.g., erosion rate, paleogeomorphology, uplift rate, sea level change, etc. Based on the systematic contrast of geomorphological features (Table 2), we conclude that the bases of the emerged parts of the older volcanoes of the WVC formed largely below sea level and were subsequently covered by fringe reefs, now forming thick limestone deposits. Subsequent uplift resulted in erosion (various stages of terraces) before 2 Ma. Later, the younger EVC formed. No limestone or terraces developed on the younger volcanoes, due to their young ages. Continuous uplift of the Coastal Range. offshore islands and the southern part of Taiwan (northern end of the Taiwan-Luzon Arc) was documented by Liew et al. (1990), Liu and Yu (1990) and Chen and Liu (1992, 1993). There is consensus that the regional uplift in this area is due to the ongoing arc-continent collision. However, the southern part of the Bashi Segment of the arc is far away from the collision zone. hence the uplift in this region probably is not related to the same event as in the northern part. As mentioned, the fore-arc basin and northern Luzon have been uplifted by the relatively buoyant extinct spreading ridge subduction (Fig. 1). It implies that the ridge collision and subduction might be the cause of the regional uplift observed in the southern Bashi Segment of the Taiwan-Luzon Arc.

\subsection{Mechanisms for the eastward shift of rolcanic front}

Constant dip of the subducting plate obviously can not account for the characteristics of the North Taiwan-Luzon Arc where two volcanic chains are separated in the south and converge in the north. As mentioned above, two tectonic events affecting the characteristics of the arc are occurring in this area. The first is the arc-continent collision in the north, the second is the ridge subduction south of the Bashi Segment. The following discussion will demonstrate that the aseismic ridge subduction plus the arc-continent collision can account for the eastward shift of the volcanic front (Fig. 6).

The arc-continent collision and the extinct seamount chain had not significantly affected the arc-trench system before $6 \mathrm{Ma}$. A typical intra-oceanic arc, the WVC, formed at the time. Consequently, the upper plate, i.e.. the Philippine Sea Plate. maybe was rotated clockwise after $4 \mathrm{Ma}$ due to the arc-continent collision (Fuller et al.. 1983: McCabe et al., 1984; Lee et al., 1991). The trench was retreating westward due to the rotation of the upper plate. Consequently, the subducting angle was shallower in the south where the buoyant extinct spreading ridge was subducting. Assuming that the magmas were generated above the subducting plate at approximately constant depths, this resulted in an 


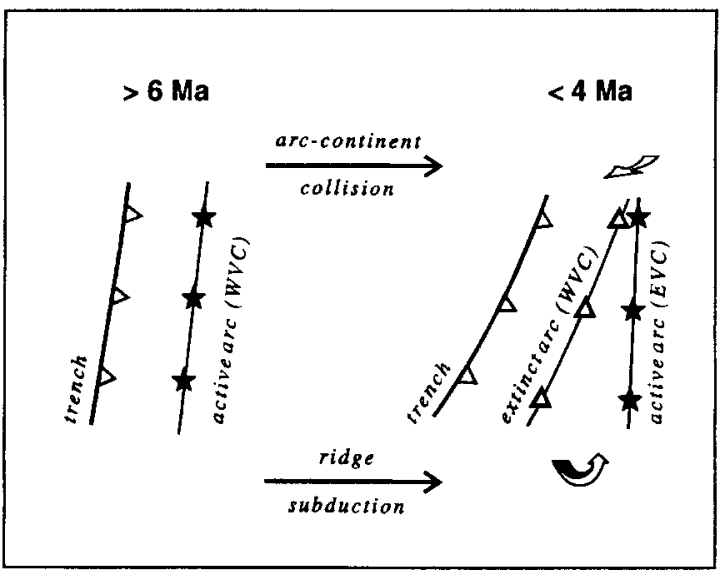

Fig. 6. The effects of arc-continent collision and ridge subduction causing the eastward shift of the Bashi Segment of the TaiwanLuzon Arc. A typical intra-oceanic arc $(W V C)$ formed before 6 Ma. The upper plate was rotated clockwise due to arc-continent collision at the northern end and caused the westward advance of the arc-trench system at ca. $4 \mathrm{Ma}$. Subsequently, the buoyant ridge started to subduct at an decreased angle. The volcanic front jumped eastward and the East Volcanic Chain was formed.

eastward shift of the volcanic front producing the EVC (cf. Figs. 2 and 6).

The above discussion is based on the assumptions of constant dip of the northern part of the arc and no crustal shortening of the upper plate. Actually, the arc-trench system of the Taiwan-Luzon Arc retreated westward relative to the Eurasian Plate due to the northwest movement of the Philippine Sea Plate (Stephan et al., 1986). This motion, however, may have been arrested due to the collision with the continental margin which resulted in the steepening of subduction angles at both ends of the TaiwanLuzon Arc. If the magma was generated at constant depth above the subducted plate, the arc-trench gap should be reduced and the volcanic front should shift westward instead of eastward. Nevertheless, the deformation and crustal shortening reported in the northern part of the Taiwan-Luzon Arc (Lewis and Hayes, 1989) could compensate for the effect of the change in subduction angle and can explain the WVC and EVC overlap in the northern Bashi Segment.

In addition to the eastward subducting Benioff-
Wadati zone along the Manila Trench, a westward subducting slab can also be observed east of Luzon along the East Luzon Trough and Philippine Trench $\left(12-18^{\circ} \mathrm{N}\right)$, i.e., two opposite subduction systems exist on either side of Luzon. This E-facing Benioff zone, however, does not exist north of $18^{\circ} \mathrm{N}$ (Fig. 4). Lewis and Hayes (1983) concluded that the East Luzon Trough is a newly formed trench system formed by the subduction of the Philippine Sea Plate and is continuously propagating northward. On the basis of our model, we would also expect the volcanic front in the southern part of the Taiwan-Luzon arc, to shift eastward (Fig. 1). Such an eastward shift has indeed been reported, although there are only a few Tertiary volcanoes in western Luzon (Fig. 1; DeBoer et al., 1980). The eastward shift, however, is not as obvious as in the Bashi Segment. We argue that the effect of the dip decreases due to buoyant ridge subduction is confined and influenced by the opposite subducting plate of the East Luzon Trough and Philippine Trench in the southern part of the arc (cf. Figs. 1 and 4).

\subsection{When did the ridge start to subduct?}

According to the current geometry of the mid-ocean ridge of the South China Sea Plate, the ridge should have collided with the Manila Trench at the very onset of subduction along this trench. A double structure, similar to those described above for the Bashi Segment, has been reported in eastern Taiwan (Huang et al., 1992, 1995) and might also be the result of ridge subduction. At $10 \mathrm{Ma}$, the Manila Trench-Taiwan-Luzon Arc system was located in a position different from its present location (Stephan et al., 1986; Teng, 1990). The collision of the ridge and older are may have occurred in the northern part of the present arc system, due to the northwestward movement of the Philippine Sea Plate. This part of the arc has been subsequently accreted upon the continental margin as part of eastern Taiwan and/or subducted underneath the Ryukyu Trench. Thus, evidence of the paleo-ridge subduction may have been destroyed in the course of the collision event. Hence it is possible only to guess when the ridge first started to subduct beneath the Taiwan-Luzon Arc.

Nur and Ben-Avraham $(1983,1989)$ proposed the following equation to calculate the time when the 
volcanic gap started to develop due to the oblique consumption of a ridge in South America:

$D=\imath \cdot \Delta t \cdot \tan \Phi$

where $D=$ distance of the volcanic gap $(\mathrm{km}), l^{\prime}=$ relative convergent rate $(\mathrm{km} / \mathrm{Ma}), \Delta t=$ time difference (Ma) and $\Phi=$ angle between subducting ridge and trench.

We can obtain the time difference, $\Delta t=5.4-4.2$ Ma from Eq. (1), assuming $D=220 \mathrm{~km}, \Phi=45^{\circ}$ (Fig. 1) and $v=41-52 \mathrm{~km} / \mathrm{Ma}$ (Gill, 1981). The age agrees well with our observation, i.e., most volcanoes of the WVC and North Luzon Segment have been extinct since the Late Miocene (Table 2; Fig. 1). Nevertheless, the model of Nur and BenAvraham is based on the assumption that the volcanic gap is deduced by the ridge consumption which was not subducted beneath but attached underneath the upper plate. The extinct mid-ocean ridge of the South China Sea Plate obviously is being subducted beneath Luzon. Their model. therefore, may not be used in the present tectonic setting of the TaiwanLuzon arc. However, as mentioned in our geodynamic model (Stage II), the ridge might have been underplated and attached to the upper plate at the beginning of the ridge-are collision and caused the temporal volcanic gap. Hence, the estimated time difference of the volcanic gap derived from Eq. (1) implies that the ridge started to affect the arc-trench system since at least 5.4-4.2 Ma.

\section{Conclusions}

Based on the geographic, geochronologic, geomorphologic and geochemical features, a double arc structure is identified in the Bashi Segment of the Taiwan-Luzon Arc. The two volcanic arc chains are separated in the south and converge north of ca. $20^{\circ} \mathrm{N}$. The strong geomorphologic contrast of these two chains suggests that the West Volcanic Chain was a largely submarine arc, which was uplifted and exposed to weathering and erosion at about $3 \mathrm{Ma}$. Combined effects of the arc-continent collision in the northern part of the arc (Taiwan) and subduction of the buoyant extinct spreading ridge south of the Bashi Segment (northern Luzon) is believed to have caused this regional uplift.
The exact onset of subduction of the ridge beneath the Taiwan-Luzon arc is difficult to determine. However, based on the observed tectonic manifestations of ridge subduction, we conclude that the ridge started to affect the arc-trench system since at least 5-4 Ma.

The ridge subduction model is proposed to account for other characteristics of the northern part of the Taiwan-Luzon Arc, including the Quaternary volcanic gap in the North Luzon Segment and the eastward shift of the volcanic front in the Bashi Segment. The subducted plate may have been torn at the continent-ocean-plate boundary due to the extra buoyancy of the extinct spreading ridge. It permitted an enriched mantle component, possibly residing in the continental lithospheric mantle, to invade the mantle wedge at about 2 Ma. Such a component, in addition to subducted continent-derived sediments. appears to be required to explain the observed spatial and temporal geochemical variations of lavas erupted in the northern part of the Taiwan-Luzon Arc.

\section{Acknowledgements}

We thank S.-s. Sun, L.S. Teng, C.Y. Huang, S.L. Chung, M.D. Kurz, S.R. Hart, B.-M. Jahn and J.H. Chen for helpful comments and discussions in various stages of this study. The help provided by $\mathrm{Y}$. Tatsumi and S. Hu in determining the K-Ar ages is greatly appreciated. The senior author would like to thank M.D. Kurz for his continual encouragement during the preparation of this paper. The manuscript was much improved by D.P. Kammer. Critical reviews and comments given by S.D. Lewis, H. Bellon and G. Pautot were helpful. This research was supported by the National Science Council (NSC842111-M-002-030-GC; NSC85-2111-M-002-048: NSC80-0202-M-001-12) and the Educational Ministry grants. Taiwan. ROC.

\section{References}

Alcaraz, A., Abad, L.F.. Tupas and M.H., 1956. The Didicas submarine volcano. Proc. 8th Pacific Sci. Congr., Manila, 1953. 2: 139-156.

Alvir. A.D. 1956. A cluster of little known Philippine volcanoes. Proc. 8th Pacific Sci. Congr.. Manila, 1953, 2: 205-206. 
Bouysse, P. and Westercamp, D., 1990. Subduction of Allantic aseismic ridges and Late Cenozoic evolution of the Lesser Antilles island are. Tectonophysics, 175: 349-380.

Cardwell, R.K., Isacks, B.L. and Karing, D.E.. 1980. The spatial distribution of earthquakes. focal mechanism solutions, and subducted lithosphere in the Philippine and northeastern Indonesian island. In: D.E. Hayes (Editor), The Tectonic and Geologic Evolution of Southeast Asian Seas and Islands. Am. Geophys. Union, Geophys. Monogr., 23: 1-36.

Chen, C.H., Shieh, Y.N.. Lee, T., Chen. C-H. and Mertzman. S.A., 1990. Nd-Sr-O isotopic evidence for source contamination and an unusual mantle component under Luzon Arc. Geochim. Cosmochim. Acta, 54: 2473-2483.

Chen. Y.G. and Liu, T.K., 1992. Vertical crustal movement of a tectonic uplifting volcanic island - Lutao. J. Geol. Soc. China, 35: 231-246.

Chen. Y.G. and Liu. T.K., 1993. Holocene radiocarbon dates in Hengchun peninsula and their neotectonic implications. J. Geol. Soc. China. 36: 457-479.

Cheng, S.N. and Yeh. Y.T., 1991. Seismotectonics of the Taiwan-Luzon region as evidenced from seismicity and focal mechanism of earthquakes. Taiwan Int. Collab. Res. for Understanding Subduction-collision system in Taiwan (TAICRUST), Taipei, Progr. Abstr., pp. 219-226.

Christian, L.B.. 1964. Post-Oligocene tectonic history of the Cagayan Basin, Philippines. Philipp. Geol.. 18: 114-147.

Chung, S.L., Jahn. B.M.. Chen. S.J., Lee, T. and Chen, C.-H.. 1995. Miocene basalts in northwestern Taiwan: evidence for EM-type mantle sources in the continental lithosphere. Geochim. Cosmochim. Acta, 59: 549-555.

Cloos. M., 1993. Lithospheric buoyancy and collisional orogenesis: subduction of oceanic plateaus, continental margins, island arcs, spreading ridges and seamounts. Geol. Soc. Am. Bull.. 105: 715-737.

DeBoer, J., Odom, L.A., Ragland. P.C., Sinder, F.G. and Tilford. N.R., 1980. The Bataan orogene: eastward subduction. tectonic rotations and volcanism in the western Pacific (Philippines). Tectonophysics, 67: 251-282

Defant M.J., Jacques, D., deBoer, J. and Joron, J.-L., 1989. Geochemistry and tectonic setting of the Luzon Arc. Philippines. Geol. Soc. Am. Bull., 101: 663-672.

Defant. M.J.. Maury, R.C., Joron, J.-L., Feigenson. M.D., Leterrier, J., Bellon, H., Jacques. D. and Richard, M.. 1990. The geochemistry and tectonic setting of the northern section of the Luzon arc, the Philippines and Taiwan. Tectonophysics. 183: 187-205.

Detrick, R.S. and Watts, A.B., 1979. An analysis of isostasy in the world's oceans. 3. aseismic ridges. J. Geophys. Res.. 84: $3637-3653$.

Fourcade, S., Maury, R.C., Defant. M.J. and McDermott, F.. 1994. Mantle metasomatic enrichment versus arc crust contamination in the Philippines: Oxygen isotope study of Batan ultramafic nodules and northern Luzon arc lavas. Chem. Geol., 114: 199-215.

Fuller, M. McCabe. R., Williams, I.S.. Almasco, J., Encina, R.Y. and Zanoria, A.S., 1983. Paleomagnetism of Luzon. In: D.E.
Hayes (Editor). The Tectonic and Geologic Evolution of Southeast Asian Seas and Islands. Part 2. Am. Geophys. Union, Geophys. Monogr. 27: 79-94.

Gill. J.B.. 1981. Orogenic Andesites and Plate Tectonics. Springer. Berlin, $387 \mathrm{pp}$.

Hamburger. M.W., Cardwell, R.K. and Isacks. B.L.. 1983. Seismotectonics of the northern Philippine island arc. In: D.E. Hayes (Editor). The Tectonic and Geologic Evolution of Southeast Asian Seas and Islands. Part 2. Am. Geophys. Union, Geophys. Monogr., 27: 1-22.

Hayes, D.E. and Lewis, S.D.. 1984. A geophysical study of the Manila Trench, Luzon. Philippines, 1. Crustal structure. gravity and regional tectonic evolution. J. Geophys. Res.. 89: $9171-9195$,

Huang, C.Y., Shyu, C.T., Lin, S.B., Lee, T.Q. and Sheu. D.. 1992. Marine geology in the arc-continent collision zone off southeastern Taiwan: implications for Late Neogene evolution of the Coastal Range. Mar. Geol.. 107: 183-212.

Huang. C.Y., Yuan, P.B.. Song. S.R.. Lin. C.W., Wang. C.. Chen. M.T., Shyu. C.T. and Karp, B., 1995. Tectonics of short-lived intra-arc basins in the arc-continent collision terrane of the Coastal Range. eastern Taiwan. Tectonics, 14: 19-38.

Jacques. D.. 1987. Geologie et petrologie de l'Archipel Babuyan et des Monte Tabungon et Cagua Nord Luzon. Philippines: implications magmatologiques et geodynamiques. These Doct. Univ. Bretagne Occidentale. 393 pp.

Juang, W.S. and Chen, J.C., 1990. Geochronology and chemical variations of volcanic rocks along the arc-continent collision zone in eastern Taiwan. Bull. Natl. Mus. Nat. Sci., 2: 89-118.

Kelleher. J. and McCann. W.. 1976. Buoyant zones, great earthquakes and unstable boundaries of subduction. J. Geophys. Res., 81: 4885-4896.

Knittel. U.. Defant. M.J. and Raczek, I.. 1988. Recent enrichment in the source region of arc magmas from Luzon island, Philippines: Sr and Nd isotopic evidence. Geology, 16: 73-76.

Knittel. U.. Trudu. A.G.. Winter. W.. Gray. C.M. and Steele. D.A., 1990). Preliminary petrochemical results from the centrul segment of the Luzon volcanic arc (Philippines): the Mankayan Mineral District. Proc. Pacific Rim Congr., 2: 217-223.

Lee, T.Q., Kissel, C.. Barrier. E., Laj, C. and Chi, W.R., 1991. Paleomagnetic evidence for a diachronic clockwise rotation of the Coastal Range, eastern Taiwan. Earth Planet. Sci. Lett. 104: $245-257$.

Lewis. S.D. and Hayes. D.E.. 1983. The tectonics of northward propagating subduction along East Luzon. Philippine island. In: D.E. Hayes (Editor). The Tectonic and Geologic Evolution of Southeast Asian Seas and Islands. Part 2. Am. Geophys. Union, Geophys. Monogr., 27: 57-78.

Lewis, S.D. and Hayes, D.E., 1989. Plate convergence and deformation, North Luzon Ridge, Philippines. Tectonophysics, 168: $221-237$

Liew, P.-M., Hsieh. M.L. and Lai, C.-K.. 1990. Tectonic significance of Holocene marine terraces in the Coastal Range. eastern Taiwan. Tectonophysics. 183: 121-127.

Lin. M.T. and Tsai. Y.B., 1981. Seismotectonics in Taiwan-Luzon area. Bull. Inst. Earth Sci. Acad. Sin.. 1: 51-82. 
Liu. C.C. and Yu, S.-B.. 1990. Vertical crustal movements in eastern Taiwan and their tectonic implications. Tectonophysics, 183: 111-119.

Lo. H.J.. 1989. Evolution of the volcanic ares of the Coastal Range, eastern Taiwan. Acta Geol. Taiwan., 27: 1-18.

Maury, R.C.. Defant, M.J. and Joron, J.-L.. 1992. Metasomatism of the sub-are mantle inferred from trace elements in Philippine xenoliths. Nature. 360:66I-663.

McCabe. R.. Kikalva. E., Col, J.T.. Malicse, A.J.. Baldauf, P.E.. Yumul. I. and Almasco. J.. 1984. Paleomagnetic results from Luron and the Central Philippines. J Geophys. Res.. 92: $555-580$

McCanm. W.R. and Sykes, L.R., 1984. Subduction of aseismic ridges heneath the Caribbean plate: implications for the tectonics and seismic potential of the northeastern Caribbean. J. Geophys. Res.. 89(B6): 4493-4519.

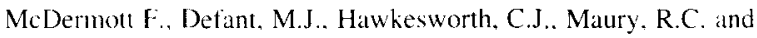
Jorm. J.L... 1993. Isotope and trace element evidence for three component mixing in the genesis of the North Luzon are lavals (Philippines). Contrib. Mineral. Petrol.. 113: 9-23.

McGeary. S. Nur, A. and Ben-Avraham, Z. 1985. Spatial gaps in arc volcanism: the effect of collision or subduction of oceanic plateiu. Tectonophysics, 119: 195-221.

Nur. A. and Ben-Avraham, Z.. 198.3. Volcanic gaps due to oblique consumption of aseismic ridges. Tectonophysics, 99: 355-362.

Nur, A. and Ben-Avraham. Z.. 1989. Oceanic plateaus and the Pacific ocean margins. In: Z. Ben-Avraham (Editor), The Evolution of the Pacilic Ocean Margins. Oxford Univ. Press, New York. NY. pp. 3-19.

Patuto1. G. and Rangin. C. 1989. Subduction of the South China Sea axial ridge below Luzon (Philippines). Earth Planet. Sci. Letl. 9?: $57-69$.

Richard. M.. Maury, R.C.. Bellon. H., Stephan. J.F., Boirat. J.M. and Calderon. A., 1986. Geology of Mt. Iraya volcano and Batlan island, northern Philippines. Philipp. J. Volcanol.. 3: $1-27$.

Ringenhach. J.C.. Pinet. N.. Stephan, J.F. and Deltail. J., 1993. Structural variety and tectonic evolution of strike-slip basins related to the Philippine Fault system. northern Luzon, Philippines. Tectonics, 12: 187-203.

Seno, T. And Kurita. K.. 1978. Focal mechanisms and tectonism in the Taiwan-Philippine region. J. Phys. Earth. 26(Suppl.): $\$ 249-\$ 263$.

Stepham. J.F. Blanchet, R., Rangin. C.. Pelletier, B., Letouzey, J. and Muller. C. 1986. Geodynamic evolution of the TaiwanLuzon-Mindoro belt since the late Eocene. Tectonophysics. 125: $2+5-268$

Suppe. J., 1988. Tectonics of arc-continent collision on both sides of the South China Sca: Taiwan and Mindoro. Acta Geol. Taiiwan., 26: 1--18.

Tatsumi Y., Hamilton. D.L. and Nesbitt, R.W.. 1986. Chemical characteristics of fluid phase released from a subducted lithosphere and origin of arc magmas: evidence from high-pressure experiments and natural rocks. J. Volcanol. Geotherm. Res.. 29: $293-309$

Tatsumoto. M. and Nakamura. Y.. 1991. Dupal anomaly in the Sea of Japan: $\mathrm{Pb}$. Nd and $\mathrm{Sr}$ isotopic variations at the eastern Eurasian continental margin. Geochim. Cosmochim. Acta. 55: $3697-.3708$.

Taylor. B. and Hayes. D.E. 1980. The tectonic cvolution of the South China Basin. In: D.E. Hayes (Editor). The Tectonic and Geologic Evolution of Southeast Asian Scas and Islands. Am. Geophys. Lnion. Geophys. Monogr., 23: 89-104.

Taylor. B. and Hayes. D.E. 1983. Origin and history of the South China Basin. In: D.E. Hayes (Editor). The Tectonic and Geologic Evolution of Southeast Asian Seas and Islands. Pant 2. Am. Geophys. Union. Geophys. Monogr.. 27: 1-22

Teng. L.S.. 1990. Geotectonic evolution of late Cenozoic arc-continent collision in Taiwan. Tectonophysics. 183:57-76

Tu. K. Flower. M.F.J. Carlson, R.W., Xhang. M. and Xie. G.. 1991. $\mathrm{Sr}$. $\mathrm{Nd}$, and $\mathrm{Pb}$ isotopic compositions of Hainan basalts (south China): implications for a sub-continental lithosphere Dupal source. Geology. 19: 567-569.

Tu. K., Flower. M.F.J. Xie. G.H.. Carlson, R.W.. Wang. Q. and Zhang. M. 1992. Magmatism in the South China Basin, I. Isotopic and trace element evidence for an endogenous Dupal mantle component. Chem. Geol. 97: 47-6.3.

Vidal, P., Dupuy. C.. Maury. R.C. and Richard, M. 1989. Mantle metasomatism above subduction zones: trace and radiogenic isotopes in xenoliths from Batan island. Philippines. Geology. 17: $1115-1118$.

Vogt. P.R.. 1973. Subduction and aseismic ridges Nature. 241: $189-191$

Vogt, P.R.. Lowrid. A.. Bracey, D.R. and Hey. R.N., 1476. Subduction of aseismic oceanic ridges: effects on shape, seismicity and other characteristics of consuming plate houndaries. Geol. Soc. Am. Spec. Pap. 172. $59 \mathrm{pp}$

Wheller. G.E.. Varne, R., Foden. J.D. and Abbott. M.J., 1987. Geochemistry of Quatemary volcanism in the Sunda-Banda are, Indonesia. and three-component genesis of island-arc basaltic magmas. J. Volcanol. Geotherm. Res. 32: 137-160.

Yang. T.-Y.. 1992. Magma evolution of North Luzon Are and the tectonic implication. Ph.D. Diss.. Vatt. Taits'an Univ. Taiped. 458 pp. (unpubl).

Yang. T.F.. Lee, T. Chen. C.-H. and Kurs. M.D. 1994. (jeochemical variations along the North Luzon Arc (Taiwan): an example of are magmatism during arc-continent collision. Annu. Meet. Geol. Soc. Am., Seattle. WA (abstract).

Yang. T.F.. Lee. T. Chen, C-H.. Kur\%. M.D. and Punongbayan. R.S. 1995a. Geochemical cvidence for the multiple source components beneath the Bashi Segment of the Taiwan-Luzon Arc. IUGG XXI General Assembly. Boulder. CO (abstract).

Yang. T.F., Tien J.L.. Chen. C-H.. Lee. T. and Punonghayan. R.S. 1995h. Fission-lrack dating of the Taiwan-L wron Arc: eruption ages and evidence for crustal contamination. I. SE Asian Earth Sci.. 11:81-93 